\title{
Using CALPUFF to determine the environmental impact of a coal mine open pit
}

\author{
H. Arregocés ${ }^{1,2}$, R. Rojano ${ }^{1,2}$, G. Restrepo ${ }^{2}$ \& L. Angulo ${ }^{3}$ \\ ${ }^{1}$ GISA Research Group, University of La Guajira, Colombia \\ ${ }^{2}$ Applied Physicochemical Processes Group, Engineering College, \\ Antioquia University, Colombia \\ ${ }^{3}$ GEAB-CIDTEC Research Group, Faculty of Engineering, \\ University of Cesar, Colombia
}

\begin{abstract}
This analysis seeks to evaluate the impacts of an open-pit coal mine located in the north of Colombia. It was used as the main tool CALPUFF, model Lagrangian, to determine the dispersion and transport of $\mathrm{PM}_{10}$ due to the emissions of the mining activities. The model was calibrated and validated with the environmental concentrations data of $\mathrm{PM}_{10}$ in 5 receivers. It was determined the contributions above of $45 \mathrm{~km}$ distances from sources. We use the concept of intake fraction, which is defined as the fraction of material or its precursor released from a source that finally is inhaled or ingested by a population. The results of the model show that the $\mathrm{PM}_{10}$ can be transported over long distances. to $50 \mathrm{~km}$ from the industrial zone of the mine, the average contribution of emissions of the mine can reach $9.12 \mu \mathrm{g} / \mathrm{m}^{3}$ and to $60 \mathrm{~km}$ contributions of $6.13 \mu \mathrm{g} / \mathrm{m}^{3}$. The modelling estimates that simulations of domain extending about $45 \mathrm{~km}$ from the source would only capture on average $54.83 \%$ of the total population intake fractions of $\mathrm{PM}_{10}$, and less for many geographic settings. The results show that the emission of $\mathrm{PM}_{10}$ is a problem of pollution on a regional scale. This analysis can serve as input to the competent authorities for better environmental management.
\end{abstract}

Keywords: CALPUFF, intake fractions, $P M_{10}$, open-pit mine.

\section{Introduction}

Currently, we are witnessing an increase in demand for energy in relation to the rapid growth of the industries and the needs of populations throughout the world. 
Although there was a decline in the use of conventional energy sources during the last decade, coal remains a primary source of energy production [1]. The extraction of this mineral can be performed via open pit methods or underground. The open pit mining generates major environmental impacts that underground mining due to its emissions of particles in the atmosphere. The sources of air pollution in the coal mining areas contribute to the pollution of the air, especially emissions of particulate material [2]. The transport of materials is the main source for generation of PM10 in the area of mining [3, 4]. The highest concentrations of $\mathrm{PM}_{10}$ are reached within the pits and nearby areas influenced by emissions into unpaved roads. The concentrations decrease gradually with the increase of the distance due to transportation, the deposition and the dispersion of particles $[5,6]$. Several studies have shown that the PM10 can reach long distances before its dry deposition [7-9]. The pollutants emitted can cause the deterioration of the quality of air in vicinity to the sources or to kilometers of sources. Cardiopulmonary diseases, pulmonary, cardiovascular and diabetes are related with the direct impacts of the opencast mines [10-13]. The population most vulnerable are children and the elderly [14].

In the north of Colombia, has developed the open pit mining and it is estimated that the impacts on the quality of air are given to mesoscale. During the past 20 years, the production in these areas has experienced a significant increase. From 1990 to 2014, the production of coal annually experiment an increase of 13.87 to 81.33 Mton [15]. Detailed studies are needed in the field of air quality for assess the environmental impact of processes and activities of the coal mining [16]. The modeling of atmospheric pollution is an attempt to describe the functional relationship between emissions and environmental concentrations and deposition produced [17]. Modeling of pollutants consistent allow to quantify the potential benefits for the health in the reduction of emissions due to estimate the partial contributions of the sources and their contributions to the environmental concentrations [18]. The intake fraction allows inferring on risk factors of morbidity in an area. The concept of intake fraction, defined as the fraction of material or its precursor released from a source that is eventually inhaled or ingested by a population [19]. The intake fractions is a simplified way of link the exposure of a contaminant in the population to emissions, it has been widely used in the assessment of the impact on human beings and the adverse effects on health [19-22].

There is a need for the construction of predictor's models of air pollution to develop strategies of control and where it is possible to quantify the cost benefits of mining companies. The CALPUFF dispersion model considered the temporal and spatial variations in the direction of the pen, as well as the permanency time of pollutant in the atmosphere [12]. For that reason, it is considered appropriate to predict the impacts of air quality in receptors to long distance of a source of emission.

We estimated the concentrations of $\mathrm{PM}_{10}$ issued in an open-pit coal mine located in the north of Colombia. It was used a model in non-stationary state for the spatial-temporal analysis of emissions of $\mathrm{PM}_{10}$ for the activities undertaken and their contributions to environmental concentrations of the area. 


\section{Methods}

\subsection{Air dispersion model}

The domain of modelling coverage area of $150 \times 150 \mathrm{~km}^{2}$ with resolution of $1 \mathrm{~km}$, which contains the open pit mines and urban centers of the department located in the area south. The minimum and maximum coordinates of the modelling domain is 10.46 North latitude-73.30 west longitude and 11.18 North latitude-72.50 west longitude (fig. 1).

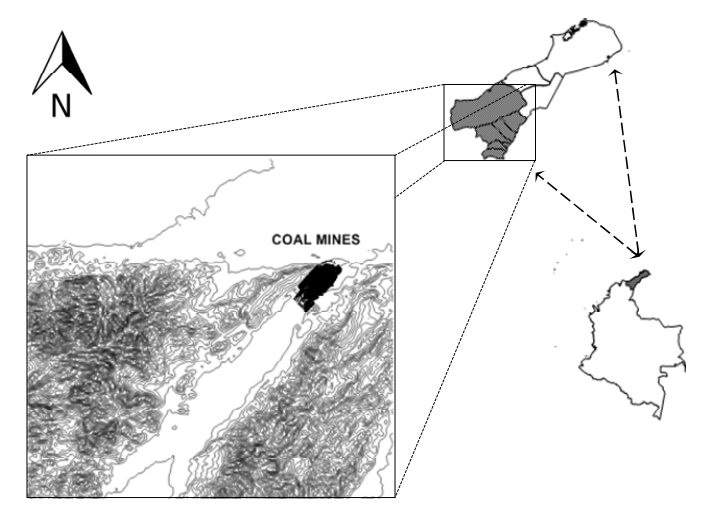

Figure 1: Location of the modelling regions used in this study.

The quantification of emissions sources in a scenario of mining is of great relevance in the modelling of air quality and represents the information needed to establish the characteristics of intensity and spatial-temporal distribution of the emissions of atmospheric pollutants. The emissions $\mathrm{PM}_{10}$ were calculated using the updates emission factors suggested by USEPA [23] and the document NPI [24] considered others factors emissions in mining activity. The general equation is determined by the following expression:

$$
E=A \times E F \times(1-E R / 100)
$$

where, $E$ is the emissions, $A$ is the rate of the activity, $E F$ is the emission factor and $E R$ is the efficiency in the reduction. The emissions contemplated the activities for the management of topsoil, Overburden and coal. In addition, emissions resulting from maintenance of roads, storage of piles of coal and wind erosion by exposed areas.

It was used the Lagrangian CALPUFF dispersion model considered suitable for predicting impacts of air quality in receptors to long distance of an emission source $[12,25]$. Recommended by its resolution at the local level in areas of complex terrain $[26,27]$. The three-dimensional winds field for CALPUFF is constructed based on observation data in surface and upper-air station using the Calmet model. For the CALMET simulations, EPA-Federal-Land-Manager- 
recommended parameter values [28]. The model parameters BIAS, RMAX1, RMAX2, TERRAD, R1, and R2 were chosen on a site-specific basis. The BIAS parameter assigns weights to the surface and upper-air stations data for each vertical layer. Surface data were given $100 \%$ of the weight $($ BIAS $=1)$ in the first layer with zero weight in the last two vertical layers $(B I A S=1)$. Equal weight was assigned to the fourth layer $(\mathrm{BIAS}=0)$ with a gradation of weights between the lower and upper for the remaining layers. The TERRAD parameter defines the radius of influence of terrain features. The parameters R1 and R2 are the distance from an observation where the observation and the initial guess field are equally weighted for surface and layers aloft, respectively. The RMAX1 and RMAX2 parameters define the maximum radius of influence for surface and upper data, respectively, over land surfaces [29].

The surface meteorological data were obtained from 6 stations located within the domain area for hourly data of temperature $\left({ }^{\circ} \mathrm{K}\right)$, precipitation $(\mathrm{mm})$, pressure $(\mathrm{mb})$, relative humidity $(\%)$, wind direction $\left(^{\circ}\right)$, wind speed $\left(\mathrm{ms}^{-1}\right)$, opaque sky cover (tenths), and Ceiling height (ft). Table 1 and fig. 2 shows the locations and the meteorological variables reported by each station.

Table 1: $\quad$ Surface stations.

\begin{tabular}{|c|c|c|c|}
\hline ID & $\begin{array}{c}\text { N Latitude } \\
(\text { Deg })\end{array}$ & $\begin{array}{c}\text { E Longitude } \\
(\text { Deg })\end{array}$ & Meteorological data \\
\hline ALM & 11.526 & 72.921 & ${ }^{\circ} \mathrm{K},{ }^{\circ}, \mathrm{ms}^{-1}, \mathrm{~mm}, \mathrm{mb}, \%$, tenths, $\mathrm{ft}$. \\
\hline CDA & 11.137 & 72.616 & ${ }^{\circ} \mathrm{K},{ }^{\circ}, \mathrm{ms}^{-1}, \mathrm{~mm}, \%$. \\
\hline PAU & 10.896 & 72.829 & ${ }^{\circ} \mathrm{K},{ }^{\circ}, \mathrm{ms}^{-1}, \mathrm{~mm}^{-} \%$. \\
\hline VALL & 10.432 & 73.249 & ${ }^{\circ} \mathrm{K},{ }^{\circ}, \mathrm{ms}^{-1}$ \\
\hline CAS & 10,950 & 72.741 & ${ }^{\circ}, \mathrm{ms}^{-1}$ \\
\hline PRO & 11.022 & 72.742 & ${ }^{\circ}, \mathrm{ms}^{-1}$ \\
\hline
\end{tabular}

The station ALM to 0600 GMT recorded the data of upper-air used. The CALMET allows to process information from other meteorological models, was introduced to the model vertical profiles of meteorological variables during the night hours through interpolations obtained by fields of MM5 model. The meteorological model was calibrated with data of direction and speed winds registered in the station La Mina belonging to the Institute of Hydrology, Meteorology and Environmental Studies of Colombia (IDEAM Acronym in Spanish). On the other hand, the dispersion model was calibrated and validated through measurements in 5 receptors. Table 2 and fig. 2 shows the identifications and coordinates of the stations.

Table 2: Environmental receptors.

\begin{tabular}{|c|c|c|c|}
\hline ID & N Latitude (Deg) & E Longitude (Deg) & Altitude (m.a.s.l.) \\
\hline RD9 & 11.099 & 72.541 & 166 \\
\hline RD11 & 10.995 & 72.773 & 155 \\
\hline RD12 & 11.023 & 72.737 & 153 \\
\hline RD14 & 10.959 & 72.779 & 150 \\
\hline RD15 & 10.950 & 72.741 & 162 \\
\hline
\end{tabular}




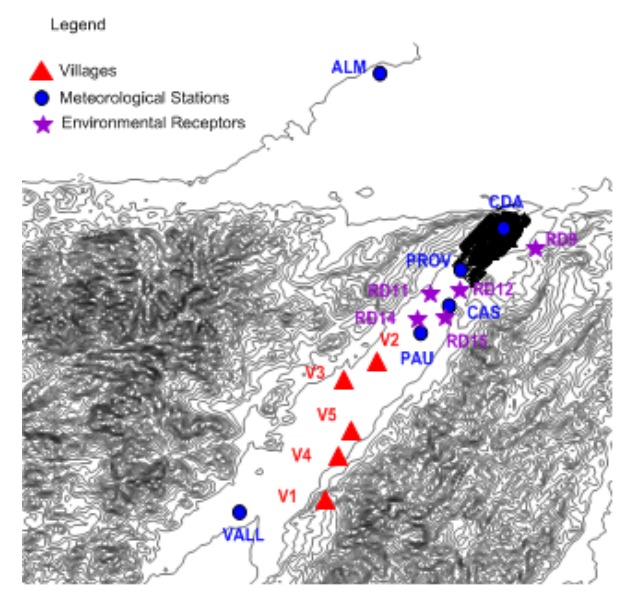

Figure 2: Location of the villages, meteorological stations and environmental receptors.

The bias correction factor in the calibration of meteorological dispersion models and between simulating a cell $\mathrm{ij}$ and the observed values are obtained by applying different statistical methods [30]. To evaluate the efficacy of the models, different statistical indices were determined. The dispersion model was calibrated with weekly averages recorded during 6 months in the receptors environment.

\subsection{Intake fraction}

To calculate the impact of emissions was determined the intake fractions in five villages located to more than $45 \mathrm{~km}$ of the mining sources (fig. 2). Information reported by the competent authorities estimated that the five villages contain a total population of 63406 in modelling time. By definition, intake fraction $(i F)$ can be calculated as

$$
i F=\frac{\sum_{i=1}^{N} P i \times B R \times C i}{Q}
$$

The modeling domain is divided into 22500 grid cells indexed by $i$. $P i$ is the population in cell $i$, derived using 2005 projection population data [31]. $C i$ is the incremental concentration at location $i\left(\mathrm{~g} / \mathrm{m}^{3}\right)$. BR is the population-average breathing rate $\left(\mathrm{m}^{3} / \mathrm{s}\right)$, for which we assume a nominal value of $20 \mathrm{~m}^{3} / \mathrm{d}$. $Q$ is the emission rate of the pollutant.

\section{Results and discussion}

\subsection{Air dispersion model}

The outputs of CALMET-CALPUFF are fields reticules per hour of parameters micro-meteorology and wind fields and temperature in three dimensions. The 
wind field module of the combines an approach of objective analysis using observations of the wind with the treatments with parameters of kinematic effects of terrain, slope flows, blocking effects and circulations. The simulation of the wind vectors is representative. The model predicted was compared with observations data confirming that the model calculations are correct. Fig. 3 shows the correlation between the simulated environmental variables (wind speed and direction) and the recorded in the station La Mina, the results provided a high reliability for the use of meteorological model in the dispersion and transport of pollutants.

(a)

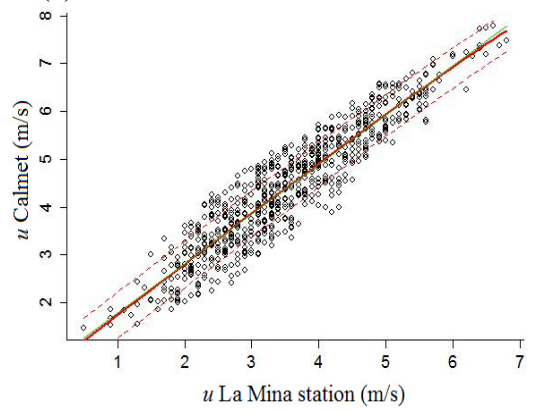

(b)

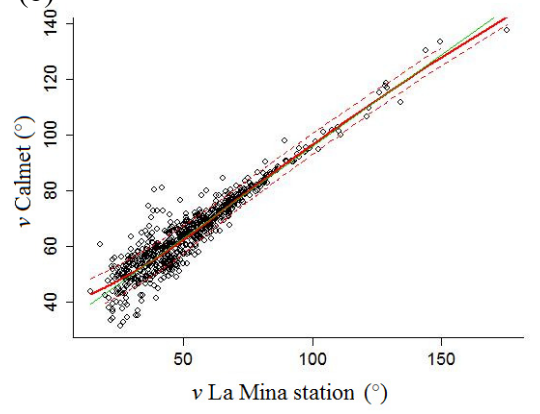

Figure 3: Regression models of meteorological variables for calibration calmet. (a) wind speed $(\mathrm{m} / \mathrm{s})$; (b) wind direction $\left(^{\circ}\right)$.

Table 3. shows the values obtained for the most frequently used metrics for evaluation of Calmet model: Coefficient of determination (R2), Coefficient of correlation (r), Root of mean square error (RMSE), Bias and Index of agreement (d). The average degree of correspondence between individual pairs of predicted values and values observed for wind speeds $(\mathrm{RSME}=0.27)$ are quite high. Suggesting suitability of the model to estimate the transport of the contaminant. Similarly, the RSME for the wind direction suggests the ability of the model to predict the dispersion of particles. The values of correlations are significantly high and consistent with the values observed in surface.

The terrain influences considerably in the magnitudes of wind speed and direction of the wind. The most frequency of speeds, in close proximity to the

Table 3: Evaluation of the meteorological model.

\begin{tabular}{|c|c|c|c|}
\hline \multirow{2}{*}{} & \multicolumn{2}{|c|}{ Meteorological variables } & \\
\cline { 2 - 4 } & Wind speed & Wind direction & Perfect value \\
\hline Equation & $0.9676 \mathrm{x}+0.0975$ & $0.6596 \mathrm{x}+30.198$ & $\mathrm{M}=1, \mathrm{~b}=0$ \\
\hline R2 & 0.94 & 0.88 & 1 \\
\hline R & 0.97 & 0.94 & 1 \\
\hline RMSE & 0.27 & 15.03 & 0 \\
\hline Bias & -0.02 & 12.43 & 1 \\
\hline D & 0.98 & 0.84 & \\
\hline
\end{tabular}


pits, was below the $3 \mathrm{~m} / \mathrm{s}$. The most frequencies in the direction of the wind registered during the period of the model was between 50 and $70^{\circ}$ with $41.34 \%$.

The concentrations were estimated weekly in each one of the receptors and were compared with the average weekly registered in the stations. The coefficients of determination are quite significant for the receptors near the pits (fig. 4). The correlation values for the receptors nearby downwind, RD11 and RD12, are quite significant shown the strong dependence of the model to describe the variability of concentrations of $\mathrm{PM}_{10}$, as is shown in table 4 . The $\mathrm{D}$ value was calculated during the period of modelling of the capacity of the model to predict the effects of the emissions to the environmental concentrations.

The slope of the linear regression line indicates the underestimation in the sources of $\mathrm{PM}_{10}$ included in the model. Considering the accuracy in the meteorological and geophysical, the slope of the regression indicates of the inaccuracy in the inventory of emissions [3]. Under this assumption, the model shows that the sources of emissions were overestimate in RD15 and underestimates in RD9. The model provides high reliability in the estimate of the dispersion of the pollutants and the variability of the concentrations in proximity to the pits. The linear regression constant shows the background of fund result of modelling. The receptors RD11 and RD12 show that the background concentrations are modelled in a range of $10.81-19.09 \mu \mathrm{g} / \mathrm{m}^{3}$.
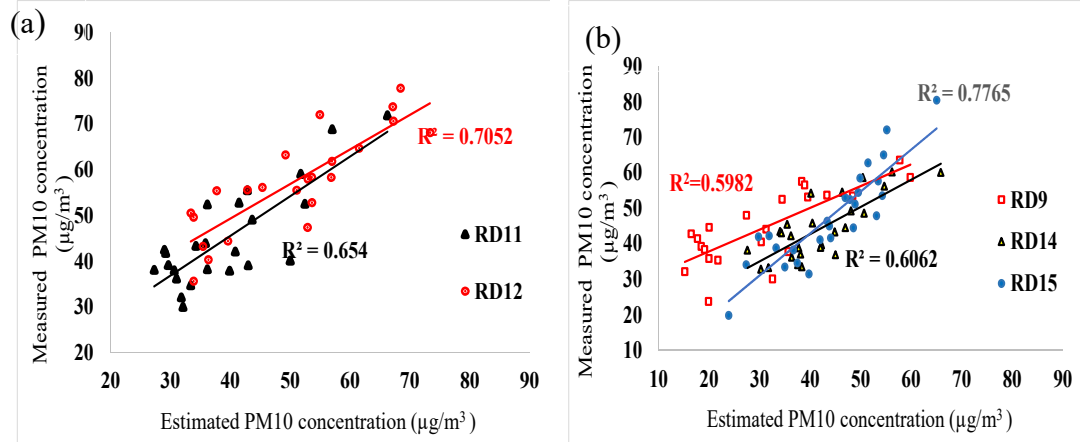

Figure 4: Comparison of measured PM10 mean concentration values from the air quality-monitoring network and predicted values from CALPUFF ( $\mu \mathrm{g} / \mathrm{m}^{3}$ ): (a) Receptor environmental RD11 and RD12; (b) Receptor environmental RD9, RD14 and RD15.

The results of Table 4 are framed within the acceptance criteria of dispersion models of air quality. To determine the reliability of the model, the criteria was used in previous studies [29, 32, 33]. The performance of a model can be considered acceptable if:

$$
\begin{gathered}
\mathrm{NMSE} \leq 0.5 \\
-0.5 \leq \mathrm{FB} \leq+0.5 \\
0.75 \leq \mathrm{MG} \leq+1.25 \\
1.00 \leq \mathrm{VG} \leq+1.25
\end{gathered}
$$


Table 4: Evaluation of the dispersion model.

\begin{tabular}{|c|c|c|c|c|c|c|}
\hline & RD9 & RD11 & RD12 & RD14 & RD15 & $\begin{array}{c}\text { Perfect } \\
\text { Value }\end{array}$ \\
\hline Equations & $\begin{array}{c}\mathrm{y}=0.61 \times \\
+25.56\end{array}$ & $\begin{array}{c}\mathrm{y}=0.87 \times \\
+10.81\end{array}$ & $\begin{array}{c}\mathrm{y}=0.76 \times \\
+19.09\end{array}$ & $\begin{array}{c}\mathrm{y}=0.77 \times \\
+12.03\end{array}$ & $\begin{array}{c}\mathrm{y}=1.18 \times \\
-4.33\end{array}$ & - \\
\hline Bias & -13.52 & -5.61 & -6.79 & -2.25 & -3.66 & 0 \\
\hline RMSE & 15.78 & 8.47 & 0943 & 6.12 & 0742 & 0 \\
\hline NMSE & 0.42 & 0.14 & 0.14 & 0.06 & 0.09 & 0 \\
\hline FB & 0.36 & 0.13 & 0.13 & 0.05 & 0.08 & 0 \\
\hline MG & 1.43 & 1.14 & 1.13 & 1.05 & 1.08 & 1 \\
\hline VG & 1.14 & 1.02 & 1.02 & 1.00 & 1.01 & 1 \\
\hline D & 0.65 & 0.83 & 0.83 & 0.86 & 0.89 & 1 \\
\hline R2 & 0.60 & 0.65 & 0.71 & 0.61 & 0.78 & 1 \\
\hline R & 0.77 & 0.81 & 0.84 & 0.78 & 0.88 & 1 \\
\hline
\end{tabular}

Legend: Bias - bias means; RMSD - root of mean square error; NMSE - normalized mean square error; FB - fractional bias; $\mathrm{MG}$ - geometric mean bias; VG - geometric mean variance; $\mathrm{d}$ - index of agreement; $\mathrm{R} 2$ - determination coefficient; $\mathrm{R}$ - correlation coefficient.

The NMSE, indicator of variance, is $<0.5$ for the weekly average of all stations, indicating that the observed concentrations and the estimated are agreed. The FB was positive for all environmental receptors and is within the accepted range, indicating that the estimated results are close to the values observed. The model tends to underestimate. The correlation coefficients are consistently acceptable for all stations showing that the reliability of the model to estimate weekly concentrations. The results show that the performance of CALPUFF to estimate concentrations of $\mathrm{PM}_{10}$ in complex terrain with multiple sources is satisfactory.

Figure 5 shows $\mathrm{PM}_{10}$ concentrations obtained by using the CALPUFF model. The results showed that the areas with the highest concentrations correspond to

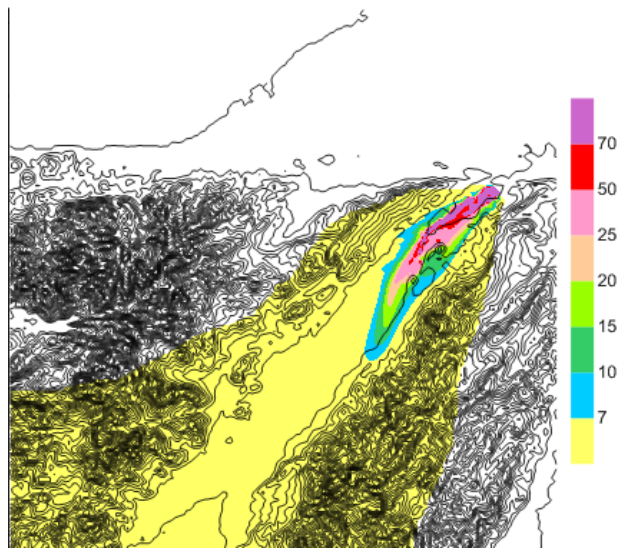

Figure 5: Mean concentrations of $\mathrm{PM}_{10}$ during the modelling. 
the location of the emission sources. $\mathrm{PM}_{10}$ concentrations decreased with increasing distance from the emission source. We estimated that greatest contributions to the environmental concentrations, downwind, are due to emissions by unpaved roads. Calculations show at distances greater than $30 \mathrm{~km}$ of the mining sources it is estimated that emissions received on receptors is given by: $57 \%$ unpaved roads, $20 \%$ due to the activities of dumps, $9 \%$ by pits, $3 \%$ by developing area of pit and $2 \%$ piles of coal. The $\mathrm{PM}_{10}$ is transported a long distance. The model shows that downwind in environmental receptors, $50 \mathrm{~km}$ from the industrial zone of the mine, the average contribution received from the emissions of the mine can reach $9.12 \mu \mathrm{g} / \mathrm{m}^{3}$ and a $60 \mathrm{~km}$ contributions of $6.13 \mu \mathrm{g} / \mathrm{m}^{3}$.

\subsection{Intake fraction}

Table 5 shows results of the intake fractions for 5 villages located to more than $45 \mathrm{~km}$ of the coalmine opencast. The intake fractions span approximately an order of magnitude across sites. The receptor with the smallest estimated intake fractions are located either close to the border of the domain, with the greatest distance from the mining sources. The results demonstrate that a significant portion of intake fraction occurs beyond $45 \mathrm{~km}$ of the source, emphasising the need for detailed long-range dispersion modelling. The modelling estimates that simulations of domain extending about $45 \mathrm{~km}$ from the source would only capture on average $54.83 \%$ of the total population intake fraction of $\mathrm{PM}_{10}$, and less for many geographic settings.

Table 5: Intake fractions for 5 villages.

\begin{tabular}{|c|c|c|c|c|c|}
\hline $\begin{array}{c}\text { Villages } \\
\text { (population) }\end{array}$ & $\bar{x}$ & $\sigma$ & $C V$ & Min & Max \\
\hline $\mathrm{V} 1(2196)$ & $2.20^{*} 10^{-3}$ & $1.34^{*} 10^{-3}$ & $6.07^{*} 10^{-1}$ & $1.81^{*} 10^{-4}$ & $4.96^{*} 10^{-3}$ \\
\hline $\mathrm{V} 2(8274)$ & $6.70^{*} 10^{-2}$ & $4.30^{*} 10^{-2}$ & $6.41^{*} 10^{-1}$ & $2.87 * 10^{-3}$ & $1.47^{*} 10^{-1}$ \\
\hline $\mathrm{V} 3(25587)$ & $6.87^{*} 10^{-2}$ & $5.10^{*} 10^{-2}$ & $7.42^{*} 10^{-1}$ & $3.74^{*} 10^{-3}$ & $1.67 * 10^{-1}$ \\
\hline $\mathrm{V} 4(8545)$ & $2.30^{*} 10^{-2}$ & $1.21^{*} 10^{-2}$ & $5.26^{*} 10^{-1}$ & $2.16^{*} 10^{-3}$ & $4.59^{*} 10^{-2}$ \\
\hline $\mathrm{V} 5(18804)$ & $5.53 * 10^{-2}$ & $3.03 * 10^{-2}$ & $0547^{*} 10^{-1}$ & $4.46^{*} 10^{-3}$ & $1.16^{*} 10^{-1}$ \\
\hline
\end{tabular}

Legend: V1-V5 - particular villages; $\bar{x}$ arithmetic mean, $\sigma$ standard deviation, $C V$ coefficient of variation, Min minimum value, Max maximum value.

The intake fraction of $\mathrm{PM}_{10}$ is related to the distance between the sources and the villages. As well as, by the population density. For example, the village V3 $\left(6.87 * 10^{-2}\right)$ presented an average most than the village V2 $\left(6.70 * 10^{-2}\right)$ which is $18 \mathrm{~km}$ closer to the sources, the number of inhabitants in V3 is approximately 3 times more than V2 (Table 5). The most variability of the fraction of intake is presented in $\mathrm{V} 3$ due to the receptivity of $\mathrm{PM}_{10}$ is influenced by the direction of the winds. The maximum values obtained shows that the impact is significant in long distances of coalmine.

Our analysis found intake fractions on the order of $10^{-2}$ for $\mathrm{PM}_{10}$, with order of magnitude variability between sites that could largely be explained by 
meteorological trends. Furthermore, we concluded that a significant portion of the intake fraction occurs beyond $45 \mathrm{~km}$ of the source. Many factors may contribute to this difference, such as population density, proximity of source, and the geographic domains employed in each study.

\section{Conclusions}

The CALPUFF represents a good tool for simulation and estimation of the environmental levels by $\mathrm{PM}_{10}$ emission of mining activities. The dispersion model estimated the particle transport to more than $60 \mathrm{~km}$ with contributions averages of concentration of $6.13 \mu \mathrm{g} / \mathrm{m}^{3}$. The greatest contributions are due to emissions by unpaved roads. The characteristics of the dispersion are determined by the direction of the winds and the topography of the terrain. The results demonstrate that a significant portion of intake fraction occurs beyond $45 \mathrm{~km}$ of the source, emphasizing the need for detailed long-range dispersion modelling. The modelling estimates that simulations in domain extending about $45 \mathrm{~km}$ from the source would only capture on average $54.83 \%$ of the total population intake fraction of $\mathrm{PM}_{10}$. Our analysis found intake fractions on the order of $10^{-2}$ for PM10, with order of magnitude variability between sites that could largely be explained by meteorological trends. These values are higher than those estimated in other realize studies. The results show significant amounts of intake of the population, increasing the possibility to acquire and develop respiratory diseases.

\section{Acknowledgement}

This project was financed by Colciencias-Cerrejon, code 1115-524-30465, the Sustainability Strategy 2013-2014. Program at the University of Antioquia (Colombia) and the University of La Guajira by supporting the development of this work.

\section{References}

[1] Díaz F. A., Analysis of the evolution of foreign direct investment in the coal mining sector in Colombia from 2002 to 2013. Apuntes del CENES, 35(61), pp. 51-83, 2016.

[2] Trivedi, R., Chakraborty, M. K., \& Tewary, B. K., Dust dispersion modeling using fugitive dust model at an opencast coal project of Western Coalfields Limited, India. Journal of Scientific and Industrial Research, 68(1), pp.71-78, 2009.

[3] Huertas, J. I., Huertas, M. E., Izquierdo, S., \& González, E. D., Air quality impact assessment of multiple open pit coal mines in northern Colombia. Journal of environmental management, 93(1), pp. 121-129, 2012.

[4] Ghose, M. K., \& Majee, S. R., Assessment of dust generation due to opencast coal mining-an Indian case study. Environmental Monitoring and Assessment, 61(2), pp. 257-265, 2000.

[5] Chaulya, S. K., Assessment and management of air quality for an opencast coal mining area. Journal of Environmental Management, 70(1), pp. 1-14, 2004. 
[6] Jones, T., Blackmore, P., Leach, M., Berube, K., Sexton, K., \& Richards, R., Characterisation of airborne particles collected within and proximal to an opencast coalmine: South Wales, UK. Environmental Monitoring and Assessment, 75(3), pp. 293-312, 2002.

[7] Song, Y., Zhang, M., \& Cai, X., PM10 modeling of Beijing in the winter. Atmospheric Environment, 40(22), pp. 4126-4136, 2006.

[8] Rodriguez, S., Querol, X., Alastuey, A., Kallos, G., \& Kakaliagou, O., Saharan dust contributions to PM10 and TSP levels in Southern and Eastern Spain. Atmospheric Environment, 35(14), pp. 2433-2447, 2001.

[9] Prospero, J. M., Long-range transport of mineral dust in the global atmosphere: Impact of African dust on the environment of the southeastern United States. Proceedings of the National Academy of Sciences, 96(7), pp. 3396-3403, 1999.

[10] Hendryx, M., \& Zullig, K. J., Higher coronary heart disease and heart attack morbidity in Appalachian coal mining regions. Preventive Medicine, 49(5), pp. 355-359, 2009.

[11] Hendryx, M., \& Ahern, M. M., Relations between health indicators and residential proximity to coal mining in West Virginia. American Journal of Public Health, 98(4), pp. 669-671, 2008.

[12] United States Environmental Protection Agency (USEPA), Revision to the guideline on air quality models: Adoption of a preferred general purpose (flat and complex terrain) dispersion model and other revisions. Federal Register, 70 (216), pp. 68218-68261, 2005. Online. www.gpo.gov/fdsys/ granule/FR-2005-11-09/05-21627/content-detail.html

[13] Qu, Y., Tang, Y., Cao, D., Wu, F., Liu, J., Lu, G., ... \& Xia, Z., Genetic polymorphisms in alveolar macrophage response-related genes, and risk of silicosis and pulmonary tuberculosis in Chinese iron miners. International Journal of Hygiene and Environmental Health, 210(6), pp. 679-689, 2007.

[14] Howel, D., Pless-Mulloli, T., \& Darnell, R., Consultations of children living near open-cast coal mines. Environmental health perspectives, 109(6), pp. 567-571, 2001.

[15] Ministerio de Minas y energias, Comportamiento de la Producción Minera en Colombia, 2015. Online. www.minminas.gov.co/analisis-minero

[16] Melody, S. M., \& Johnston, F. H., Coal mine fires and human health: What do we know?. International Journal of Coal Geology, 152 (1), pp. 114, 2015.

[17] Canepa, E., \& Builtjes, P. J. H., Methodology of model testing and application to dispersion simulation above complex terrain. International journal of environment and pollution, 16(1-6), pp. 101-115., 2001.

[18] Levy, J. I., Spengler, J. D., Hlinka, D., Sullivan, D., \& Moon, D., Using CALPUFF to evaluate the impacts of power plant emissions in Illinois: model sensitivity and implications. Atmospheric Environment, 36(6), pp. 1063-1075, 2002.

[19] McKone, T. E., Evans, J. S., Nazaroff, W. W., Margni, M. D., Jolliet, O., Smith, K. R., \& Bennett, D. H., Defining intake fraction. Environmental Science \& Technology, 36(9), pp. 206A-211A, 2002. 
[20] Curci, G., Cinque, G., Tuccella, P., Visconti, G., Verdecchia, M., Iarlori, M., \& Rizi, V., Modelling air quality impact of a biomass energy power plant in a mountain valley in Central Italy. Atmospheric environment, 62(1), pp. 248-255, 2012.

[21] van Zelm, R., Huijbregts, M. A., den Hollander, H. A., Van Jaarsveld, H. A., Sauter, F. J., Struijs, J., \& van de Meent, D., European characterization factors for human health damage of PM 10 and ozone in life cycle impact assessment. Atmospheric Environment, 42(3), pp. 441453, 2008.

[22] Zhou, Y., Levy, J. I., Hammitt, J. K., \& Evans, J. S., Estimating population exposure to power plant emissions using CALPUFF: a case study in Beijing, China. Atmospheric Environment, 37(6), pp. 815-826, 2003.

[23] United States Environmental Protection Agency (USEPA), Emissions Factors \& AP 42, Compilation of Air Pollutant Emission Factors, 1995. Online. www3.epa.gov/ttnchie1/ap42/

[24] National Pollutant Inventory (NPI), Emission estimation technique manual for Mining and Processing of Non-Metallic Minerals, 2014. Online. www.npi.gov.au/resource/emission-estimation-technique-manual-miningand-processing-non-metallic-minerals-version-20.

[25] Scire, J. S., Strimaitis, D. G., \& Yamartino, R. J., A user's guide for the CALPUFF dispersion model. Earth Tech, Inc. C., 2000. Online. www.src.com/calpuff/.

[26] Ghannam, K., \& El-Fadel, M., Emissions characterization and regulatory compliance at an industrial complex: an integrated MM5/CALPUFF approach. Atmospheric Environment, 69(1), pp. 156-169, 2013.

[27] MacIntosh, D. L., Stewart, J. H., Myatt, T. A., Sabato, J. E., Flowers, G. C., Brown, K. W., \& Sullivan, D. A., Use of CALPUFF for exposure assessment in a near-field, complex terrain setting. Atmospheric Environment, 44(2), pp. 262-270, 2010.

[28] Fox. T., Clarification on EPA-FLM Recommended Settings for CALMET, 2009. Online. www.weblakes.com/Newsletter/2009/Sep2009.html

[29] Rood, A. S., Performance evaluation of AERMOD, CALPUFF, and legacy air dispersion models using the winter validation tracer study dataset. Atmospheric Environment, 89(1), pp. 707-720, 2014.

[30] Pielke R. A., Mesoscale meteorological modeling, Academic press:USA, pp. 373-405, 2013.

[31] DANE www.dane.gov.co/index.php/poblacion-y-demografia/proyecciones -de-poblacion.

[32] Gulia, S., Kumar, A., \& Khare, M., Performance evaluation of CALPUFF and AERMOD dispersion models for air quality assessment of an industrial complex. Journal of Scientific \& Industrial Research, 74(1), pp. 302-307, 2015.

[33] Langner, C., \& Klemm, O., A comparison of model performance between AERMOD and AUSTAL2000. Journal of the Air \& Waste Management Association, 61(6), pp. 640-646, 2011. 